\title{
ELECTROPHORESIS AND BIOPHYSICAL CHARACTERIZATION OF SARCOSINE OXIDASE - MODIFICATION OF MAGNETIC NANOPARTICLES
}

\author{
${ }^{1}$ Dagmar UHLIROVA, ${ }^{2}$ Catia DAMIÃO, ${ }^{1}$ Martina STANKOVA, ${ }^{1}$ Michaela VSETICKOVA, \\ 'Zuzana TOTHOVA, ${ }^{3}$ Branislav RUTTKAY-NEDECKY, ${ }^{4}$ Marta KEPINSKA, ${ }^{1}$ Josef RUZICKA, \\ ${ }^{4}$ Halina MILNEROWICZ, ${ }^{5}$ Warawan EIAMPHUNGPORN, ${ }^{1,3,4}$ Rene KIZEK \\ ${ }^{1}$ Department of Research and Development, Prevention Medicals s.r.o., Studénka-Butovice, \\ Czech Republic, EU, uhlirova@preventionmedicals.cz \\ ${ }^{2}$ Faculty of Pharmacy University of Lisboa, Avenida Professor Gama Pinto, Lisboa, Portugal, EU, \\ catiassdamiao@gmail.com \\ ${ }^{3}$ Department of Human Pharmacology and Toxicology, University of Veterinary and Pharmaceutical \\ Sciences Brno, Czech Republic, EU, kizek@sci.muni.cz \\ ${ }^{4}$ Department of Biomedical and Environmental Analyses, Faculty of Pharmacy with Division of Laboratory \\ Diagnostics, Wroclaw Medical University, Wroclaw, Poland, EU, \\ zalewska.m@gmail.com \\ ${ }^{5}$ Department of Clinical Microbiology and Applied Technology, Faculty of Medical Technology, Mahidol \\ University, Salaya, Nakhon Pathom, Thailand, warawan.eia@mahidol.ac.th \\ https://doi.org/10.37904/nanocon.2019.8510

\begin{abstract}
Sarcosine oxidase (SOX) is a flavoprotein and cleaves sarcosine to form hydrogen peroxide, glycine and formaldehyde. Sarcosine is commonly found in muscle, tissues, toothpaste and food supplements. Increased amounts have been found in patients with prostate cancer. SOX is an enzyme suitable for the enzymatic determination of sarcosine. Biotechnological applications require increased stability of used enzymes. In our study, we focused on temperature $\left(5,15,20,30,35,40,50\right.$ and $\left.60{ }^{\circ} \mathrm{C}\right)$ and $\mathrm{pH}$-dependent changes $(\mathrm{pH} 5$, $5.5,6,6.5,7,7.5,8,8.5,9,9.5,10$ and 10.5) in SOX activity. We used native polyacrylamide gel electrophoresis (Native-PAGE) to monitor changes in SOX. Native-PAGE can be sensitive to any process that changes either the charge or conformation of the protein, so they are excellent for detecting various chemical degradations, aggregations, binding changes, acidic, alkaline or denaturing in general. In addition, SOX was bound to the surface of magnetic nanoparticles (SPIONs). When SOX was bound to SPIONs and lyophilized, SOX activity remained unchanged (100\%) after 6 months.
\end{abstract}

Keywords: Sarcosine oxidase; sarcosine; enzymatic colorimetric assay; thermostability; Native-PAGE

\section{INTRODUCTION}

Quantitative determination of sarcosine is important in clinical chemistry, food and fermentation industries. Increases in sarcosine levels are associated with Alzheimer, dementia, prostate cancer, colorectal cancer, stomach cancer and sarcosinemia [1,2]. Sarcosine oxidase is a FAD dependent oxidoreductase found in the cell cytoplasm which participates in oxidation-reduction biological process [3-5]. This enzyme is a flavoprotein that catalyzes the oxidative demethylation of sarcosine and forms equimolar of formaldehyde, glycine and hydrogen peroxide [6,7]. Many organisms produce intracellular sarcosine oxidase eggs, bacteria, mammals or even plants. Monomeric sarcosine oxidase (MSOX) is one of the simplest members of eukaryotic and 
prokaryotic enzymes that catalyze similar oxidation reactions with different secondary or tertiary proteins. The MSOX contains 390 amino acids and has a molecular weight of $43 \mathrm{kDa}[7,8]$.
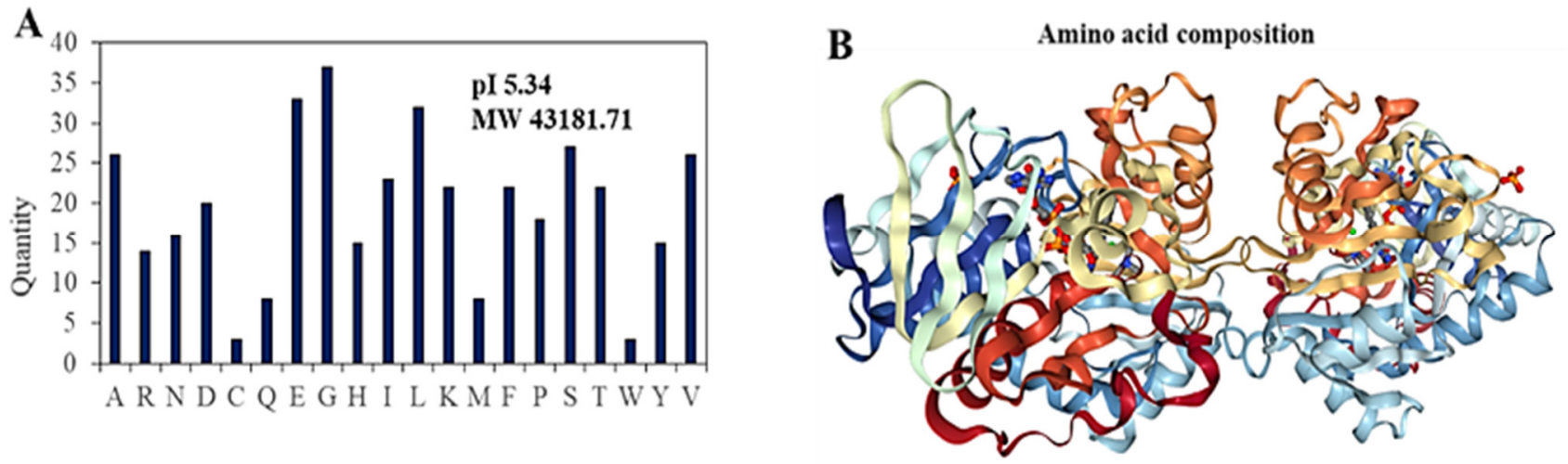

Figure 1 Sarcosin oxidase (SOX). Amino acid composition of SOX (A). MSOX structural model from Expasy database (B).

We used native polyacrylamide gel electrophoresis (Native-PAGE) to monitor changes in sarcosine oxidase. Native gel or non-denaturing electrophoresis takes place without denaturing agents. While, for example, electrophoretic mobility of proteins in SDS-PAGE depends primarily on their molecular weight, in Native-PAGE proteins migrate through the gel based on total charge, hydrodynamic size, and shape. The sensitivity of electrophoresis is determined by the size of the gel pores.

\section{MATERIAL AND METHODS}

\section{Chemicals}

All chemicals that were used for gel electrophoresis were purchased from VWR (USA) and other chemicals were purchased from Merck (USA) at a purity $>99 \%$. All plastic materials used (tubes, tips) in this study were purchased from Eppendorf (Germany). Working standard solutions were prepared daily by dilution of the stock solutions. Deionised water was prepared by using the reverse osmosis equipment Aqual 25 (Czech Republic), and was further purified by using an ELGA apparatus equipped with a UV lamp (United Kingdom). The resistance was $18 \mathrm{M} \Omega$ and the $\mathrm{pH}$ was measured using the $\mathrm{pH}$ meter WTW (Czech Republic).

\section{Preparation of SPION nanoparticles and their modification with SOX}

SPION nanoparticles were prepared according to the procedure published elsewhere [9]. Shortly, SPIONs nanoparticles were prepared from $\mathrm{Fe}\left(\mathrm{NO}_{3}\right)_{3}$ and a solution of borohydride in $3.5 \% \mathrm{NH}_{3}$. The synthesis was carried out with stirring at $100{ }^{\circ} \mathrm{C}$ for 2 hours. After 2 hours, the mixture was allowed to stir overnight at room temperature. The prepared iron nanoparticles were washed and their surface was modified by the reaction with $\mathrm{HAuCl}_{4}$, the mixture was stirred for 3 hours. Trisodium citrate was then added and the mixture was stirred again overnight. The resulting SPIONs nanoparticles were washed, dried and ready for further use. For further modification, the SPIONs nanoparticles were weighed, washed and SOX was attached to them using chitosan and tripolyphosphate. 


\section{Spectrophotometry}

A UV/VIS UV-3100PC, VWR (USA) single-beam spectrophotometer was used to record the UV-VIS spectra. The VIS spectrum was measured every $2 \mathrm{~nm}$ in the range of 350-700 nm in plastic cuvettes with an optical path of $1 \mathrm{~cm}$. The Infinite F50 (Tecan, Switzerland) was used for measurement on a polystyrene microtiter plate (Gama Group a.s., Czech Republic). Automated spectrometric measurements: BS-300 chemical analyzer from Mindray (China), cuvettes $5 \times 6 \times 30 \mathrm{~mm}$, optical path $5 \mathrm{~mm}$, a volume of the reaction mixture in the cuvette $180-500 \mu \mathrm{L}$. Photometric detector measuring at wavelengths: $340,405,450,510,546,578$, 630 , and $670 \mathrm{~nm}$. Reagents and samples were placed on the cooled sample holder $\left(4{ }^{\circ} \mathrm{C}\right)$ and automatically pipetted directly into plastic cuvettes. Incubation proceeded at $37^{\circ} \mathrm{C}$. The mixture was consequently stirred. The washing steps by distilled water $(18 \mathrm{M} \Omega)$ were done in the midst of the pipetting. Apparatus was operated using software BS-300 (Mindray, China) and Qinslab (Prevention Medicals, Czech Republic).

\section{Temperature study}

SOX (1 mU) was placed in a Eppendorf tube and sealed in a thermoblock (Mastercycler NEXUS, Eppendorf, Germany). Temperatures $\left(5,15,20,30,35,40,50\right.$ and $\left.60{ }^{\circ} \mathrm{C}\right)$ were set for $60 \mathrm{~min}$. Thereafter, a spectrophotometric study of SOX activity was performed as a color product formation. Lyophilization of SOX to SPIONs was carried out for $48 \mathrm{~h}$ at $-80^{\circ} \mathrm{C}$ and a pressure of about $0.1 \mathrm{mb}$ (LABCONCO, USA).

\section{Gel electrophoresis}

For Native PAGE, we used a $6 \%$ gel $(6 \%$ acrylamide / bis-acrylamide, $0.16 \%$ TEMED and $44 \mu \mathrm{M}$ ammonium peroxodisulfate), using $60 \mathrm{mM}$ HEPES and $40 \mathrm{mM}$ imidazole as the running buffer. Sarcosine oxidase enzyme samples were prepared in Britton-Robinson buffer $(0.04 \mathrm{M}$ phosphoric acid, $0.04 \mathrm{M}$ acetic acid, and $0.04 \mathrm{M}$ boric acid) at varying pHs. Samples were maintained at $\mathrm{pH} 5,5.5,6,6.5,7,7.5,8,8.5,9,9.5,10$ and 10.5 for 1 hour at $37{ }^{\circ} \mathrm{C}$ and at room temperature $\left(25^{\circ} \mathrm{C}\right)$. Samples were then mixed with the loading buffer $(2: 1)$ and applied to the gel. $50 \%$ glycerol with $0.01 \%$ bromophenol blue was used as the loading buffer. The concentration of sarcosine oxidase per well was $10 \mu \mathrm{g}$. Electrophoresis was run at $150 \mathrm{~V}$ for 1 hour. Gels were stained with silver to visualize the results. Subsequently, the gels were scanned and evaluated by Colortest.

\section{RESULTS AND DISCUSSION}

Analytical approaches to sarcosine analysis are based on its detection by HPLC or CE techniques. Trinderreaction based enzymatic methods can be used as low-cost tools in urine detection [10]. Enzymes often change their activity depending on the surrounding conditions, so their study is important [2]. In our preliminary study, the effect of $\mathrm{pH}$ and temperature on SOX activity was monitored. To determine the effect of temperature on the SOX reaction, the enzyme activity was measured at various temperatures $(5,15,20,30,35,40,50$ and $60{ }^{\circ} \mathrm{C}$ ). For determination of the enzymatic thermostability, the enzyme solution was incubated for $60 \mathrm{~min}$. For SOX activity measurement, the concentration of SOX of $1 \mu \mathrm{g} / \mu \mathrm{L}$ was used. For the reaction with substrate (sarcosine), phosphate buffer $(\mathrm{pH}=8), 4$-aminoantipyrine $(4-\mathrm{AAP})$, sarcosine oxidase (SOX) and diluted horseradish peroxidase (HRP) were used. Standard solutions of sarcosine were prepared at different concentrations $(90,188,375,750,1000,1300 \mu \mathrm{M})$. The reactions were performed in 96-well microtiter plates and the absorbance was measured by a microplate reader. The total volume of each reaction was $300 \mu \mathrm{L}$. Reactions were performed by adding $50 \mu \mathrm{L}$ of sarcosine solution and $250 \mu \mathrm{L}$ of reaction mixture.

The rate of formation of colored product (absorbance) was immediately measured at $540 \mathrm{~nm}$ at laboratory temperature every minute for $60 \mathrm{~min}$. The stability of SOX was up to $40^{\circ} \mathrm{C}$. At temperatures above $45^{\circ} \mathrm{C} \mathrm{SOX}$ activity was $70-80 \%$ of the maximum value. At temperatures of $50-55^{\circ} \mathrm{C}$, SOX activity was about $10 \%$ and 
above $65{ }^{\circ} \mathrm{C}$ SOX was already inactivated. At temperatures in the range of 4 to $20{ }^{\circ} \mathrm{C}$, SOX activity was observed between 95 - $99 \%$ of maximum activity. In lyophilized SOX, the activity was between $95-110 \%$ of maximum activity. Similar results were obtained from Tong et al. [11]. Next, SOX was incubated in reaction buffer at different pHs $(5.0,5.5,6.0,6.5,7.0,7.5,8.0,8.5,9.0,9.5,10.0$ and 10.5) for one hour at room temperature and at $37{ }^{\circ} \mathrm{C}$. Subsequently, a reaction with sarcosine $(100 \mu \mathrm{M})$ was performed and individual SOX samples were loaded onto Native-PAGE. SOX activity was at a low pH (5 and 5,5) $40-60 \%$, at pH6 an increase in SOX activity to $80-90 \%$ was recorded and a peak of SOX activity was between pH 7 and 8 (100\%). SOX activity was $80-70 \%$ of the maximum activity above pH 8.3 bands are visible on the gel. The most significant bands are those at the front of the gel, with shifts and color changes depending on the $\mathrm{pH}$ being most visible. The sample at $\mathrm{pH} 5$ is very bright, but all three samples are observable. For all others, the lanes are darker with increasing $\mathrm{pH}$, but from $\mathrm{pH}$, the first band is visibly losing. Similar results were obtained at $25{ }^{\circ} \mathrm{C}$. When SOX ( $100 \mathrm{mg} / \mathrm{g}$ of nanoparticles) was immobilized to the SPION surface, the converted SOX activity was about $90-100 \%$ of the maximum activity. In addition, SOX on the surface of SPIONs nanoparticles could be lyophilized. Lyophilized enzyme showed long-term stability under normal conditions (after more than 6 months its activity was $95-100 \%$ of maximum activity).

A

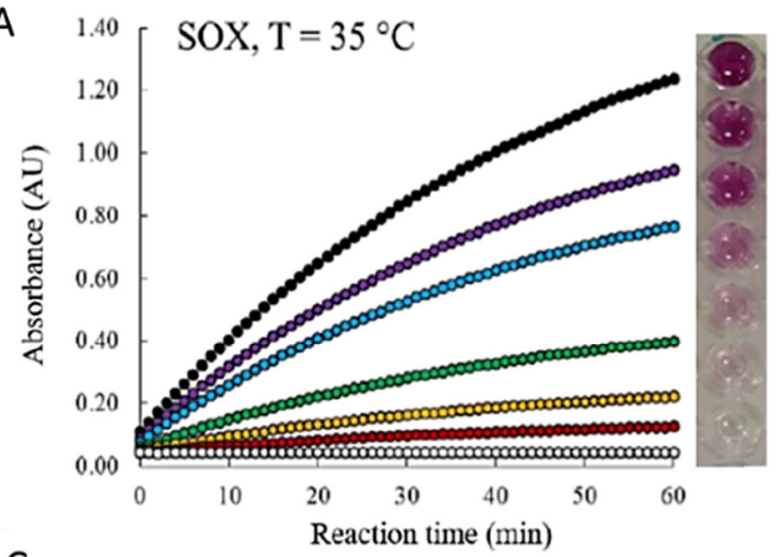

C

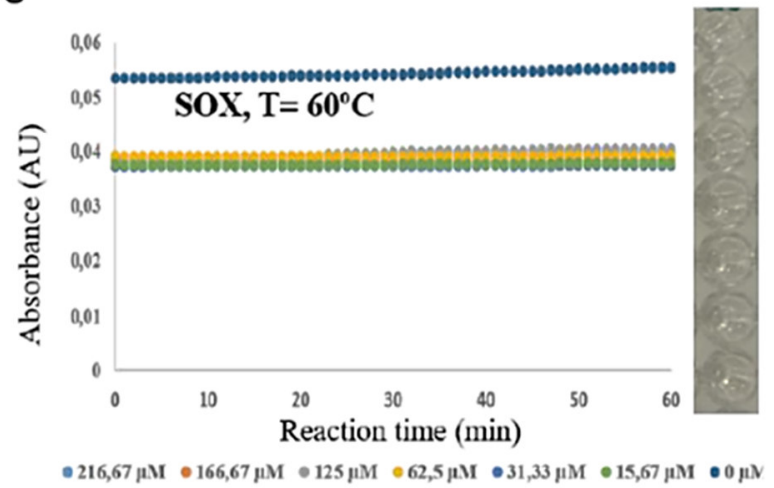

B

D
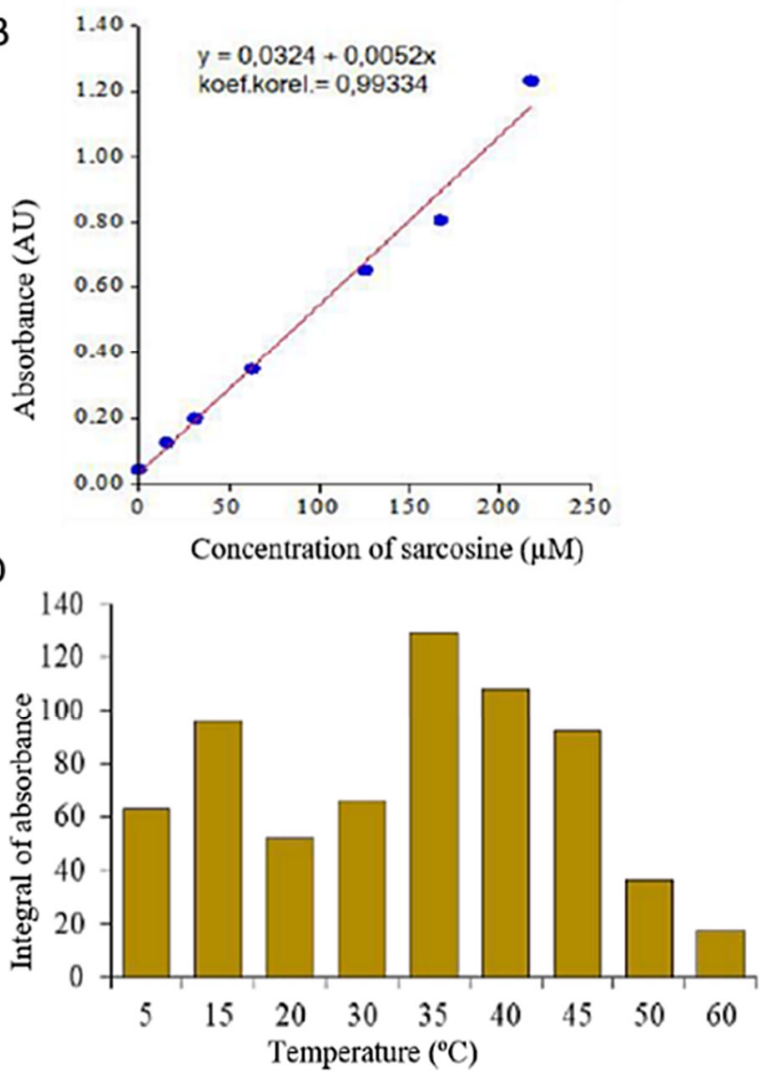

Figure 2 Tracking SOX activity after exposure to elevated temperature. Dependence between absorbance and sarcosine concentration $(0,15,30,60,125,170$ and $220 \mu \mathrm{M})$ over time. The signal of SOX activity has increased every minute during 1 hour after SOX has been exposed to $35^{\circ} \mathrm{C}$ for 60 minutes (A). Calibration curve of sarcosine - concentration ranges from $0 \mu \mathrm{M}$ to $220 \mu \mathrm{M}$ (B). SOX activity after incubating the enzyme at $60{ }^{\circ} \mathrm{C}$ for 60 minutes $(\mathrm{C})$. Changes in the integral of SOX signal when exposed to different temperatures $\left(5,15,20,30,35,40,50\right.$ and $\left.60^{\circ} \mathrm{C}\right)$ for 60 minutes showing that SOX is relatively unstable when exposed to temperatures up to $45^{\circ} \mathrm{C}(\mathrm{D})$. 
A $\quad$ B

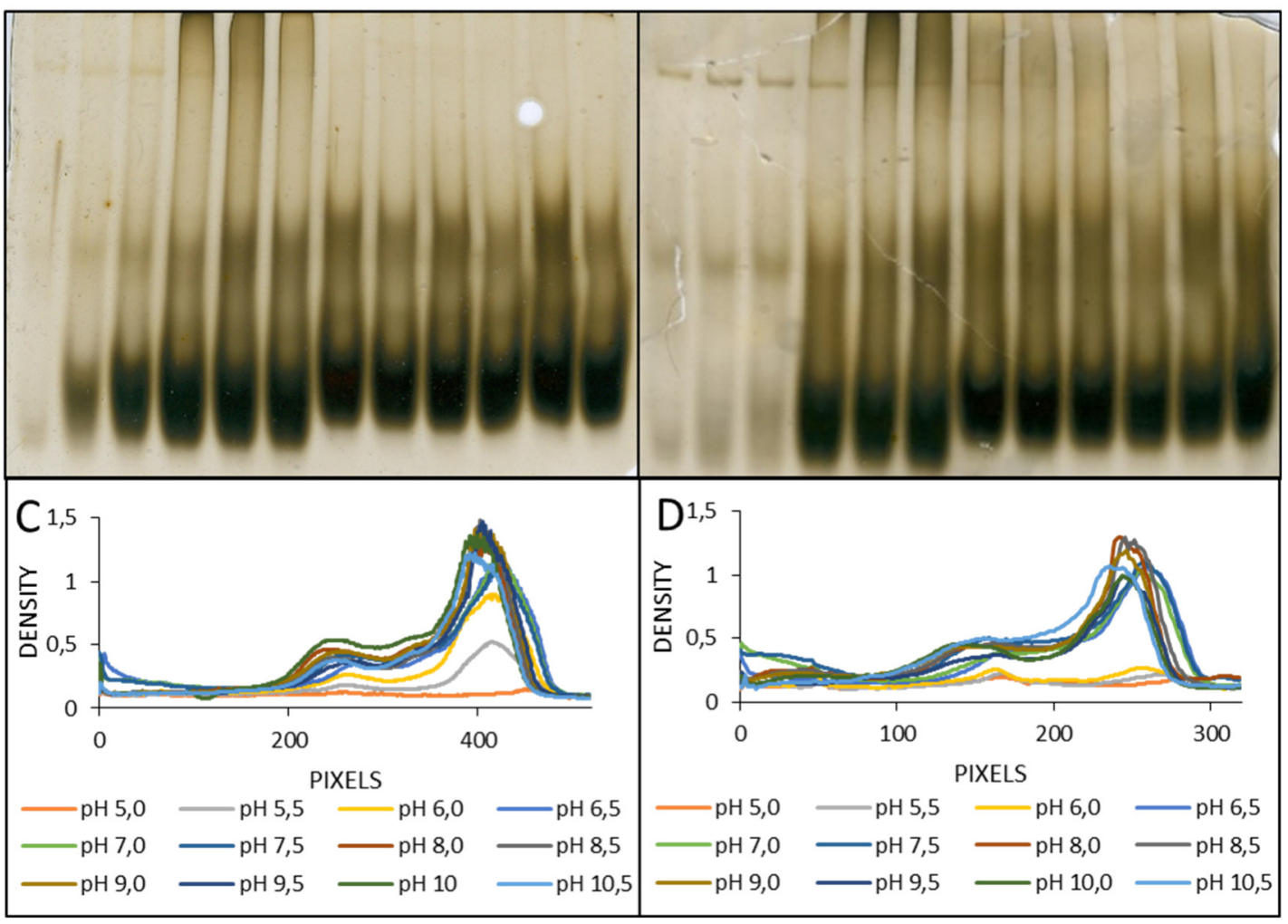

Figure 3 Native-PAGE SOX incubated for $60 \mathrm{~min}$ at $\mathrm{pH}(5.0,5.5,6.0,6.5,7.0,7.5,8.0,8.5,9.0,9.5,10.0$ and 10.5) A) at room temperature; B) at $37^{\circ} \mathrm{C} ; \mathrm{C}$ ) and D) A summary graphs of the evaluated sample paths in the gels over the graphs in the Colortest. Dependence is the distance in pixels per density. Density is defined as $\log \left(I_{0} / I\right)$, where $I_{0}=255$ and $I$ is our measured density. Further conditions are given in Material and Methods.

\section{CONCLUSION}

Rapid diagnostics is essential for effective initiation of treatment. Sarcosine is extensively studied as a potential tumor marker for prostate cancer $[12,13]$. The Trinder reaction with SOX provides a very good analytical response [14,15]. The critical part of analytical determination is SOX. The work has shown that SOX is relatively stable when exposed to temperatures up to $50^{\circ} \mathrm{C}$. Another critical parameter is $\mathrm{pH}$. The best $\mathrm{pH}$ for this enzymatic reaction is $\mathrm{pH} 8$ [9]. On Native-PAGE, it is apparent that SOX at a pH lower than 8 has an altered conformation. The work has shown that SOX is relatively stable when exposed to temperatures up to $50{ }^{\circ} \mathrm{C}$. When SOX was bound to SPIONs and lyophilized, SOX activity was about $100 \%$ after 6 months.

\section{ACKNOWLEDGEMENTS}

The work was supported by the SARKOTEST 165/2015, H2020 ERASMUS+ and international collaboration project of The European Technology Platform for Nanomedicine.

\section{REFERENCES}

[1] PUNDIR, C. S., DESWAL, R., KUMAR, P. Quantitative analysis of sarcosine with special emphasis on biosensors: a review. Biomarkers, vol., no. pp. 8. 
[2] HTOO, K. P. P., YAMKAMON, V., YAINOY, S., SUKSRICHAVALIT, T., VISESHSINDH, W., EIAMPHUNGPORN, W. Colorimetric detection of PCA3 in urine for prostate cancer diagnosis using thiol-labeled PCR primer and unmodified gold nanoparticles. Clin. Chim. Acta, 2019, vol. 488, no. pp. 40-49.

[3] JORNS, M. S., CHEN, Z. W., MATHEWS, F. S. Structural Characterization of Mutations at the Oxygen Activation Site in Monomeric Sarcosine Oxidase. Biochemistry, 2010, vol. 49, no. 17, pp. 3631-3639.

[4] LAHHAM, M., PAVKOV-KELLER, T., FUCHS, M., NIEDERHAUSER, J., CHALHOUB, G., DANIEL, B., KROUTIL, W., GRUBER, K., MACHEROUX, P. Oxidative cyclization of N-methyl-dopa by a fungal flavoenzyme of the amine oxidase family. J. Biol. Chem., 2018, vol. 293, no. 44, pp. 17021-17032.

[5] ABE, Y., SHOJI, M., NISHIYA, Y., AIBA, H., KISHIMOTO, T., KITAURA, K. The reaction mechanism of sarcosine oxidase elucidated using FMO and QM/MM methods. Phys. Chem. Chem. Phys., 2017, vol. 19, no. 15, pp. 98119822.

[6] STEENKAMP, D. J., HUSAIN, M. The effect of tetrahydrofolate on the reduction of electron transfer flavoprotein by sarcosine and dimethylglycine dehydrogenases. Biochem. J., 1982, vol. 203, no. 3, pp. 707.

[7] STANKOVA, M., RUTTKAY-NEDECKY, B., DOCEKALOVA, M., DOCEKALOVA, M., UHLIROVA, D., MIKELOVA, R., HOSNEDLOVA, B., RUZICKA, J., KIZEK, R. Fotometrická detekce aminokyseliny sarkosinu za využití jeho hydrolýzy sarkosin oxidasou. Chem. Listy, 2019, vol. 111, no. 10, pp. 603-609.

[8] TRICKEY, P., WAGNER, M. A., JORNS, M. S., MATHEWS, F. S. Monomeric sarcosine oxidase: structure of a covalently flavinylated amine oxidizing enzyme. Struct. Fold. Des., 1999, vol. 7, no. 3, pp. 331-345.

[9] UHLIROVA, D., STANKOVA, M., DOCEKALOVA, M., HOSNEDLOVA, B., KEPINSKA, M., RUTTKAY-NEDECKY, B., RUZICKA, J., FERNANDEZ, C., MILNEROWICZ, H., KIZEK, R. A Rapid Method for the Detection of Sarcosine Using SPIONs/Au/CS/SOX/NPs for Prostate Cancer Sensing. Int. J. Mol. Sci., 2018, vol. 19, no. 12, pp. 29.

[10] MAZZU-NASCIMENTO, T., LEAO, P., CATAI, J. R., MORBIOLI, G. G., CARRILHO, E. Towards low-cost bioanalytical tools for sarcosine assays for cancer diagnostics. Anal. Methods, 2016, vol. 8, no. 40, pp. 73127318.

[11] TONG, Y. J., XIN, Y., YANG, H. L., ZHANG, L., WANG, W. Efficient improvement on stability of sarcosine oxidase via poly-lysine modification on enzyme surface. Int. J. Biol. Macromolec., 2014, vol. 67, no. pp. 140-146.

[12] SREEKUMAR, A., POISSON, L. M., RAJENDIRAN, T. M., KHAN, A. P., CAO, Q., YU, J. D., LAXMAN, B., MEHRA, R., LONIGRO, R. J., LI, Y., NYATI, M. K., AHSAN, A., KALYANA-SUNDARAM, S., HAN, B., CAO, X. H., BYUN, J., OMENN, G. S., GHOSH, D., PENNATHUR, S., ALEXANDER, D. C., BERGER, A., SHUSTER, J. R., WEI, J. T., VARAMBALLY, S., BEECHER, C., CHINNAIYAN, A. M. Metabolomic profiles delineate potential role for sarcosine in prostate cancer progression. Nature, 2009, vol. 457, no. 7231, pp. 910-914.

[13] KHAN, A. P., RAJENDIRAN, T. M., BUSHRA, A., ASANGANI, I. A., ATHANIKAR, J. N., YOCUM, A. K., MEHRA, R., SIDDIQUI, J., PALAPATTU, G., WEI, J. T. The role of sarcosine metabolism in prostate cancer progression. Neoplasia, 2013, vol. 15, no. 5, pp. 491-501.

[14] YAMKAMON, V., PHAKDEE, B., YAINOY, S., SUKSRICHAWALIT, T., TATANANDANA, T., SANGKUM, P., EIAMPHUNGPORN, W. Development of sarcosine quantification in urine based on enzyme-coupled colorimetric method for prostate cancer diagnosis. EXCLI journal, 2018, vol. 17, no. pp. 467.

[15] LAN, J. M., XU, W. M., WAN, Q. P., ZHANG, X., LIN, J., CHEN, J. H., CHEN, J. Z. Colorimetric determination of sarcosine in urine samples of prostatic carcinoma by mimic enzyme palladium nanoparticles. Anal. Chim. Acta, 2014, vol. 825, no. pp. 63-68. 